\title{
HEPATOPROTECTIVE ROLE OF CISSUS QUADRANGULARIS ON LEAD ACETATE-INDUCED LIVER INJURY IN FEMALE WISTAR RATS
}

\author{
NEETHU JAYAN, SUSMITA DAS, SANTHOSH KUMAR R, SABINA EP, ASHA DEVI S* \\ Department of Biomedical Sciences, School of Bioscience and Technology, VIT University, Vellore, Tamil Nadu, India. \\ Email: ashaselvaraj74@gmail.com
}

Received: 16 May 2017, Revised and Accepted: 21 July 2017

\begin{abstract}
Objectives: Several heavy metals like lead acetate can accumulate in the body due to exposure to the metal for a prolonged period. One of the possible mechanisms involved with lead toxicity is oxidative stress is for which liver is the target organ. The primary aim of this study was to examine the hepatoprotective role of methanolic stem extract from the herb Cissus quadrangularis on induced lead acetate liver injury in female Wistar rats.
\end{abstract}

Methods: The course of the study was for 14 days. The animals were separated into 5 groups: two being control and negative and the other 3 groups based on the dosage of the methanolic extract of the plant was given. The dosage of the plant extract given was once daily for all days of course study. During the last 7 days, lead acetate was injected in the animals ( $25 \mathrm{mg} / \mathrm{kg}$ of body weight). The sacrifice was done 14 days later and the blood and liver samples were taken, which is then used for different antioxidant enzymatic assays.

Results: Significant reduced $(\mathrm{p}<0.05)$ antioxidant levels and increased lipid peroxidation levels were observed in lead acetate treated group which was ameliorated by the action of extract from Cissus quadrangularis fusiformis. Histopathological study also supported the finding.

Conclusion: The results of the different antioxidant enzymatic assays supported the hepatoprotective role of methanolic stem extract of the plant Cissus quadrangularis over induced lead acetate injury in wistar female rats.

Keywords: Antioxidant, Cissus quadrangularis, Hepatoprotective, Lead acetate.

(C) 2017 The Authors. Published by Innovare Academic Sciences Pvt Ltd. This is an open access article under the CC BY license (http://creativecommons. org/licenses/by/4. 0/) DOI: http://dx.doi.org/10.22159/ajpcr.2017.v10i11.20018

\section{INTRODUCTION}

Lead being a highly toxic metal and poison can affect the nervous, gastrointestinal, renal, and hematic systems over gradual accumulation of the metal in body for years. Lead toxicity can even result in fatal conditions [1]. Lead toxicity occurs when lead is ingested or breathed in along with other dust particles. Lead toxicity can result in various mental and physical symptoms according to the individual's health status and duration of exposure to the metal, while children being more prone to the condition. Lead has been associated with various forms of cardiovascular disease, nephrotoxicity, cancer, etc. Excess lead in body will reduce the intellectual performance and cognitive development in children, while in adults, it will increase incidence of blood pressure and cardiovascular diseases. Lead is known for inducing over production of reactive oxygen species (ROS) and thereby enhancing lipid peroxidation and unsaturated fatty acid contents in membranes [2]. Enhanced ROS production results in oxidative stress, and ROS itself is a byproduct in many tissue level degenerative reactions and later affects the regular metabolism in cellular level by damaging its components. Cissus quadrangularis commonly referred as "bone setter" is native, to countries like, India, Thailand, Africa, etc., is being used for medicinal purposes from centuries back. Its applications include healing bone fracture and tissue repair, preventing osteoporosis, regulation of blood sugar levels, weight loss, irregularity in menstrual period, cholesterol lowering, and various other analgesic, antimicrobial, and anti-inflammatory effects [3,4]. Usually, the dried stem powder is used as the healing agent. Phytochemical analysis of $C$. quadrangularis revealed the presence of $\beta$ carotenoids, for which scientific proofs are available for its hepatoprotection activity $[5,6]$. Hence, this current study was conducted to examine the hepatoprotective role efficiency of $C$. quadrangularis methanolic stem extract over induced lead acetate toxicity in female Wistar rats.

\section{METHODS}

\section{Chemicals}

Lead acetate and all other reagents and chemicals utilized for the experiment were of analytically graded.

Preparation of methanolic extract from plant material

The stems of herb C. quadrangularis were collected from Vellore in the month of July. The fresh plant stem is then subjected to shade drying at about $45^{\circ} \mathrm{C}$ for few days. The stems after drying thoroughly were then powdered (100 g) using an electric grinder. The fine powder obtained after multiple processing of grinding and sieving is then mixed with methanol. The mixture is then left overnight at room temperature. The next day, the solution of plant extract along with methanol is filtered out separately using filter paper from the mixture. The solution obtained is then kept for complete drying at $40^{\circ} \mathrm{C}$ for about $4-5 \mathrm{hrs}$ in a hot air oven. The extract left behind after drying is then kept at $4^{\circ} \mathrm{C}$ [6]. Whenever needed for the experiments, it was used by dissolving in distilled water.

\section{Animals}

30 female Wistar albino rats with weights varying in the range of 150$200 \mathrm{~g}$ were used for the current study. Animals were kept in normal room temperature of $24 \pm 2^{\circ} \mathrm{C}$ in hygienic atmosphere. The animals were fed with normal laboratory diet. The Institutional Animal Ethical Committee of VIT University, Vellore, was the approving authority for the experimental protocol (VIT/IEAC/12/July23/28).

\section{Experimental design}

Animals were categorized into 5 groups containing 6 animals in each group. Group I (normal control) was treated with normal saline for 14 days. Group II (negative) was treated with lead acetate $(25 \mathrm{mg} / \mathrm{kg}$ of body weight) from days 8 to 14 . Group III (low dosage) was fed with methanolic extract of $C$. quadrangularis $(50 \mathrm{mg} / \mathrm{kg}$ of the body weight) once daily for 14 days and lead acetate $(25 \mathrm{mg} / \mathrm{kg}$ of body weight) for 
the past 7 days. Group IV (medium dosage) was administered with $100 \mathrm{mg} / \mathrm{kg}$ of body weight of methanolic extract of C. quadrangularis for 14 days and lead acetate ( $25 \mathrm{mg} / \mathrm{kg}$ of body weight) for past 7 days (once daily). Group V (high dosage) was treated with methanolic extract of $C$. quadrangularis ( $200 \mathrm{mg} / \mathrm{kg}$ of body weight) once daily for 14 days along with lead acetate $(25 \mathrm{mg} / \mathrm{kg}$ of body weight) for the past 7 days. Lead acetate was injected intraperitoneally, and methanolic extract was given orally. Body weights of the rats were assessed on the initial and final days. After $24 \mathrm{hrs}$ of last dosage, the animals were sacrificed by method of decapitation, and trunk blood was collected. Liver tissue was excised instantly in sterile conditions and washed with ice-cold normal saline to remove the fat depositions and blood stains. Later, it was blot dried and the weight of the tissue is taken. These tissue samples were utilized for the histopathological and antioxidant studies.

\section{Biochemical estimation}

The collected trunk blood was left to clot for few minutes followed with centrifugation at $3000 \mathrm{rpm}$ for 10 minutes at $4^{\circ} \mathrm{C}$ was done for serum separation. The serum obtained was utilized in estimating the marker enzymes in the liver: Aspartate transaminase (AST) and alkaline phosphatase (ALP). It was done using diagnostic kits which were commercially available from Autospan Diagnostics, India. The total protein estimation was done according to the standard protocol of Lowry method [7].

\section{Preparation of homogenate}

In ice-cold phosphate buffer ( $0.1 \mathrm{M}$ with $\mathrm{pH}$ 7.4) containing $1.17 \%$ $\mathrm{KCl}, 10 \%$ liver homogenate was prepared. A part of this prepared homogenate was utilized in estimating the reduced glutathione (GSH) level and lipid peroxidation. The homogenate remainings were again centrifuged at $10,000 \mathrm{rpm}$ for 10 minutes at a temperature of $4^{\circ} \mathrm{C}$. The supernatant obtained is then used to carry out the antioxidant enzymatic assays: Superoxide dismutase (SOD) and catalase (CAT).

\section{Estimation of reduced GSH}

$1 \mathrm{ml}$ of homogenated tissue was added to $1 \mathrm{ml}$ of 5\% TCA. Then, it is thoroughly mixed to precipitate the protein. The tubes were incubated at room temperature for $30 \mathrm{~min}$ and centrifuged for $15 \mathrm{~min}$ at $2500 \mathrm{rpm}$. To $0.4 \mathrm{ml}$ of supernatant obtained by centrifugation, $0.4 \mathrm{ml}$ of Ellman's Reagent (DTNB) was added. Then, to make the volume up to $3 \mathrm{ml}$, phosphate buffer $(0.1 \mathrm{M})$ was added to the samples. On reaction with Ellman's reagent, reduced GSH produces a compound in yellow color. The absorbance of colored compound is read at $412 \mathrm{~nm}$ against the blank reagent. The unit of the result is expresses in nmole/min $\mathrm{mg}$ protein [8].

\section{Lipid peroxidation estimation}

By estimating the quantity of malondialdehyde (MDA) formed, the oxidative stress extension can be quantitatively detected since MDA is an end product of lipid peroxidation. This is considered as a biomarker in evaluating the toxic stress levels in cells. The protocol followed for performing this assay was according to the method of Ohkawa et al. [9]. $1 \mathrm{ml}$ of $10 \%$ trichloroacetic acid (TCA) was added to equal volume of homogenate kept at room temperature for 10 minutes. The mixture was centrifuged at $2500 \mathrm{rpm}$ for 15 minutes and $1 \mathrm{ml}$ of supernatant obtained was added to $1 \mathrm{ml}$ of TCA $(0.67 \%)$, mixed, and kept for 20 minutes in boiling water bath. Then, the tubes were kept under running tap water to cool and $5 \mathrm{ml}$ of n-butanol: Pyridine and distilled water $(1 \mathrm{ml})$ were added to the tubes. Again, after centrifuging the mixture, the supernatant of butanol layer obtained was separated and the absorbance was read at $532 \mathrm{~nm}$. The results were expressed in nmoles MDA formed/mg protein.

\section{SOD assay}

The enzyme SOD acts as a defensive agent against some highly reactive free radicals such as hydroxyl radicals by converting it into oxygen and hydrogen peroxide. To determine SOD activity, Marklund's pyrogallol autoxidation method was followed [10]. $0.5 \mathrm{ml}$ of supernatant from homogenate was mixed in $0.15 \mathrm{ml}$ of chloroform and $0.25 \mathrm{ml}$ absolute ethanol. For 15 minutes, the tubes were left in shaker followed by centrifugation. To the supernatant of $0.5 \mathrm{ml}, 2 \mathrm{ml}$ of $0.1 \mathrm{M}$ Tris $\mathrm{HCl}$ with pH 8.2 was mixed along with $0.5 \mathrm{ml}$ of pyrogallol solution and distilled water of $1 \mathrm{ml}$. With a time interval of 1 minute between each reading, the absorbance was read at $420 \mathrm{~nm}$ for 3 minutes. The results of the enzymatic activity were expressed in $\mathrm{U} / \mathrm{mg}$ protein.

\section{CAT activity estimation}

Hydrogen peroxide formed from toxic activities is able to get converted to oxygen and water with the action of enzyme CAT. The reaction mixture tubes with $1 \mathrm{ml}$ phosphate buffer $(0.01 \mathrm{M}$ and $\mathrm{pH} 7.0), 0.5 \mathrm{ml}$ of $0.2 \mathrm{M} \mathrm{H}_{2} \mathrm{O}_{2}, 0.4 \mathrm{ml}$ distilled water, and $0.1 \mathrm{ml}$ of supernatant from homogenate were incubated for 1 minutes at room temperature. Potassium dichromate: Glacial acetic acid solution was added to the tubes followed by putting in boiling water bath for 15 minutes. Tubes are allowed to cool under tap water and the absorbance reading was taken at $570 \mathrm{~nm}$. The results were expressed in $\mu$ mole of $\mathrm{H}_{2} \mathrm{O}_{2}$ consumed/minutes mg protein [11].

\section{Histological examination}

Liver samples excised from each group were placed in $10 \%$ neutral buffered solution of formalin. The liver tissue slices were then processed using an automated tissue processor followed by embedding in wax. The sections were cut out with $5 \mu \mathrm{m}$ thicknesses using Leica microtome RM 2155 and stained the samples using Hematoxylin and Eosin (H \& E). The stained slides were then observed under the light microscope.

\section{Statistical analysis}

The statistical study was done using the ANOVA method followed with Dunnett's test, and all the data were expressed in mean \pm standard error mean. Statistically, $\mathrm{p}<0.05$ was considered statistically significant. It was carried out utilizing the software Graphpad Instat software Inc., Version 3.06, San Diego, USA.

\section{RESULTS}

Body and organ weight

The gain in body weight, changes, and variations in liver weight on the administration of lead acetate and pre-treatment effect of C. quadrangularis on lead acetate intoxicated rats are given in Table 1. Body weight got reduced significantly in Group II when compared to Group I. However, the body weight got increased in Groups III, IV, and $V$ by $10.50 \%, 14.44 \%$, and $15.74 \%$, respectively, when compared to the Group II (negative).

\section{Biochemical estimation}

Levels of serum total protein along with levels of liver marker enzymes are depicted in Table 2. Increased levels of marker enzymes ALP and AST were observed in Group II (negative) when compared with the control Group I indicating liver impairment. Groups III, IV, and V exhibited decreased levels of the marker enzymes implying that the lead acetate activity got counteraction by C. quadrangularis administration. Serum total protein levels were also reduced significantly in Group II when compared with Group I and the groups pretreated with C. quadrangularis also exhibited values close to the normal value and significant increase in comparing with Group II.

\section{Antioxidant assays}

Table 3 depicts the effect of $C$. quadrangularis over the actions of various antioxidant enzymes like SOD, CAT, etc. In case of liver damage, the lipid peroxidation levels are meant to get highly elevated, and it was clearly observed in Group II (negative) when compared to Group I, and in the groups pretreated with $C$. quadrangularis, the lipid peroxidation levels were significantly reduced when compared to Group II (negative). Reduced GSH level was also reduced significantly in Group II in comparison with Group I. Groups III, IV, and V exhibited increased levels of reduced GSH in comparison with Group II. Table 3 also depicts the effect of $C$. quadrangularis over the actions of some antioxidant enzymes such as SOD and CAT. Levels of these enzymes were decreased significantly in Group II (negative) when compared to Group I (control). 
Table 1: Effect of lead acetate administration on body and organ weight with or without the administration of $C$. quadrangularis

\begin{tabular}{llll}
\hline Groups & Initial body weight & Final body weight & Absolute organ weight \\
\hline Group I (control) & $176.33 \pm 4.25$ & $208.66 \pm 6.29$ & $4.36 \pm 0.27$ \\
Group II (negative) & $177.5 \pm 3.09$ & $180.5 \pm 3.67$ & $3.31 \pm 0.21^{\mathrm{a} *}$ \\
Group III (low dosage) & $170.33 \pm 5.83$ & $190.33 \pm 5.78$ & $4.13 \pm 0.29^{\mathrm{b} *}$ \\
Group IV (medium dosage) & $173.83 \pm 4.96$ & $203.16 \pm 3.07$ & $4.25 \pm 0.27^{\mathrm{b} *}$ \\
Group V (high dosage) & $180.16 \pm 3.91$ & $214.16 \pm 5.83$ & $4.36 \pm 0.23^{\mathrm{b} *}$ \\
\hline
\end{tabular}

Values are mean \pm SEM $n=6 .{ }^{*} \mathrm{p}<0.05$ and comparisons were as follows: ${ }^{\mathrm{a} G r o u p ~ I ~ v e r s u s ~ G r o u p s ~ I I, ~ I I I, ~ I V, ~ V ; ~}{ }^{\mathrm{b}}$ Group II versus Groups III, IV, V. C. quadrangularis: Cissus quadrangularis

Table 2: Effect of Cissus quadrangularis on serum total protein and other liver function markers over lead acetate administration

\begin{tabular}{|c|c|c|c|}
\hline Groups & AST (IU/L) & $\operatorname{ALP}(I U / L)$ & Total protein $(\mathrm{g} / \mathrm{dL})$ \\
\hline Group I (control) & $74.74 \pm 5.03$ & $177.53 \pm 4.95$ & $10.43 \pm 0.22$ \\
\hline Group II (negative) & $90.93 \pm 3.9^{a *}$ & $330.76 \pm 7.80^{\mathrm{a} *}$ & $9.26 \pm 0.09^{\mathrm{a} *}$ \\
\hline Group III (low dosage) & $81.95 \pm 3.5^{\mathrm{a} * \mathrm{~b} *}$ & $300.05 \pm 4.20^{\mathrm{a} * \mathrm{~b} *}$ & $9.75 \pm 0.08^{\mathrm{b} *}$ \\
\hline Group IV (medium dosage) & $76.56 \pm 5.18^{\mathrm{b} *}$ & $261.75 \pm 7.12^{\mathrm{a} * \mathrm{~b} *}$ & $10.3 \pm 0.08^{\mathrm{b} *}$ \\
\hline Group V (high dosage) & $72.36 \pm 3.52^{\mathrm{b} *}$ & $216.14 \pm 9.21^{\mathrm{b} *}$ & $11.19 \pm 0.07^{\mathrm{a} * \mathrm{~b} *}$ \\
\hline
\end{tabular}

Values are mean \pm SEM $n=6 .{ }^{*} \mathrm{p}<0.05$ and comparisons were as follows: ${ }^{\mathrm{a}}$ Group I versus Groups II, III, IV, V; ${ }^{\mathrm{b}}$ Group II versus Groups III, IV, V. C. quadrangularis: Cissus

quadrangularis, AST: Aspartate transaminase, ALP: Alkaline phosphatase

Table 3: Lead acetate effect on antioxidant enzymes in control and the experimental animals (with or without the prior administration of Cissus quadrangularis)

\begin{tabular}{|c|c|c|c|c|c|}
\hline Groups & $\begin{array}{l}\text { Group I } \\
\text { (control) }\end{array}$ & $\begin{array}{l}\text { Group II } \\
\text { (negative) }\end{array}$ & $\begin{array}{l}\text { Group III (low } \\
\text { dosage) }\end{array}$ & $\begin{array}{l}\text { Group IV (medium } \\
\text { dosage) }\end{array}$ & $\begin{array}{l}\text { Group V (high } \\
\text { dosage) }\end{array}$ \\
\hline SOD (U/mg protein) & $13.80 \pm 0.61$ & $8.18 \pm 0.49^{a *}$ & $8.82 \pm 0.13$ & $9.18 \pm 0.15^{\mathrm{b} *}$ & $9.72 \pm 0.27^{\mathrm{b} *}$ \\
\hline CAT ( $\mu$ mole of $\mathrm{H}_{2} \mathrm{O}_{2}$ consumed/min mg protein) & $80.53 \pm 0.54$ & $52.20 \pm 0.71^{\mathrm{a} *}$ & $64.78 \pm 0.72^{\mathrm{a} * \mathrm{~b} *}$ & $73.39 \pm 1.12^{\mathrm{b} *}$ & $75.39 \pm 1.17^{\mathrm{b} *}$ \\
\hline GSH peroxidase ( $\mu \mathrm{g}$ of GSH utilized/min mg protein) & $42.00 \pm 1.44$ & $27.88 \pm 0.43^{\mathrm{a} *}$ & $32.91 \pm 0.97^{\mathrm{b} *}$ & $35.25 \pm 0.14^{\mathrm{b} *}$ & $37.81 \pm 0.80^{\mathrm{b} *}$ \\
\hline Lipid peroxidation (n moles/mg protein) & $6.06 \pm 0.62$ & $10.77 \pm 0.52^{\mathrm{a} *}$ & $9.47 \pm 0.18^{\mathrm{a} *}$ & $7.05 \pm 0.46^{\mathrm{a} * \mathrm{~b} *}$ & $6.14 \pm 0.39^{\mathrm{b} *}$ \\
\hline
\end{tabular}

Values are mean \pm SEM $n=6 .{ }^{*} \mathrm{p}<0.05$ and comparisons were as follows: ${ }^{\mathrm{a}}$ Group I versus Groups II, III, IV, V; ${ }^{\mathrm{b}}$ Group II versus Groups III, IV, V. C. quadrangularis: Cissus quadrangularis, GSH: Glutathione, SOD: Superoxide dismutase, CAT: Catalase

In other three groups, the levels of these enzymes were restored back to normal when compared with Group II. It indicates the protective effect of $C$. quadrangularis.

\section{Histopathological examinations}

Fig. 1 exhibits the histological variations on the effects of lead and pretreatment with C. quadrangularis. Group I, normal control (Fig. 1a) depicts a normal histology, but Group II, lead acetate-induced group (Fig. 1b) shows damaged histology, characterized by congested, and dilated central vein and hepatocytes showing necrosis, karyolysis, and pyknosis of nuclei which are indications of hepatocellular injury. Chronic inflammatory cell infiltration in the portal tract with destruction of the periportal hepatocytes was observed in the Group III (Fig. 1c). In Group IV, minimal with congested and dilated central veins and congestion of vessels in portal tract with minimal inflammation with more of normal hepatocytes were observed (Fig. 1d). In group V, almost normal liver architecture with minimal inflammation in the portal tract and normal hepatocytes (Fig. 1e) were observed.

\section{DISCUSSION}

Liver being the major site of xenobiotic metabolism can exhibit the elevated quantity of toxic substances which may lead to impairment in liver function by changing the antioxidant reserve [12]. There are several causes responsible for liver damage for which lead accumulation in the body is also a reason. ALP and AST are considered as wellknown markers of hepatic injuries. Elevated levels of these enzymes in the serum of lead acetate treated animals indicate hepatic damage as they will flow out from the liver, because of tissue deterioration, to the blood. The antioxidant defense depletion or increase in production of free radicals will result in deterioration of antioxidant-prooxidant balance, which later leads to oxidative stress-induced apoptosis [13]. Pre-treatment with $C$. quadrangularis could prevent lipid peroxidation either directly or indirectly by free radical scavenging through GSH. Under oxidative stresses, GSH will get changed to GSH disulfide (GSSG), and its depletion leads in lipid peroxidation. Hence, GSH can be used as marker for checking the oxidative stress levels. Declined levels of GSH in lead acetate treated Group II are may be due to the increased utilization of GSH. Pre-treatment using methanolic extract of $C$. quadrangularis resulted in restoring the GSH levels. It can be due to the fundamental reduction in hepatic peroxidative actions leading to restoration of GSH. SOD and CAT act as a guarding system against ROS [12,14]. In this study, SOD levels were drastically decreased in lead acetate-induced Group II animals. The decreased levels of these enzymes can be due to the fact that inactivation of $\mathrm{H}_{2} \mathrm{O}_{2}$ scavenging enzymes resulting from the SOD inactivation by superoxide anions. SOD and CAT are mutual supporting teams of the antioxidant enzyme. Pre-treatment with methanolic extract of $C$. quadrangularis could prevent depletion in the actions of SOD and CAT effectively by scavenging on the radicals responsible for the depletion of these enzymes. The anabolic steroid isolated from CQ found to act on estrogen receptors of bone cells. C. quadrangularis depicted an interesting fact that though the plant is a popular remedy for a variety of ailments and a range of formulations has been marketed, little effort has been made to verify its purity, quality, and efficacy through scientific screening $[15,16]$.

\section{CONCLUSION}

C. quadrangularis has hepatoprotective activity against lead acetateinduced liver injury. The dominant mechanisms involved in the hepatoprotection activity of $C$. quadrangularis consist of restoration of the tissue level SOD, GSH, and CAT enzyme levels implying the restoration of inherent protection apparatus by various phytochemical constituents present in C. quadrangularis. However, further detailed studies toward clinical and molecular levels are required to understand the exact action mechanism. 


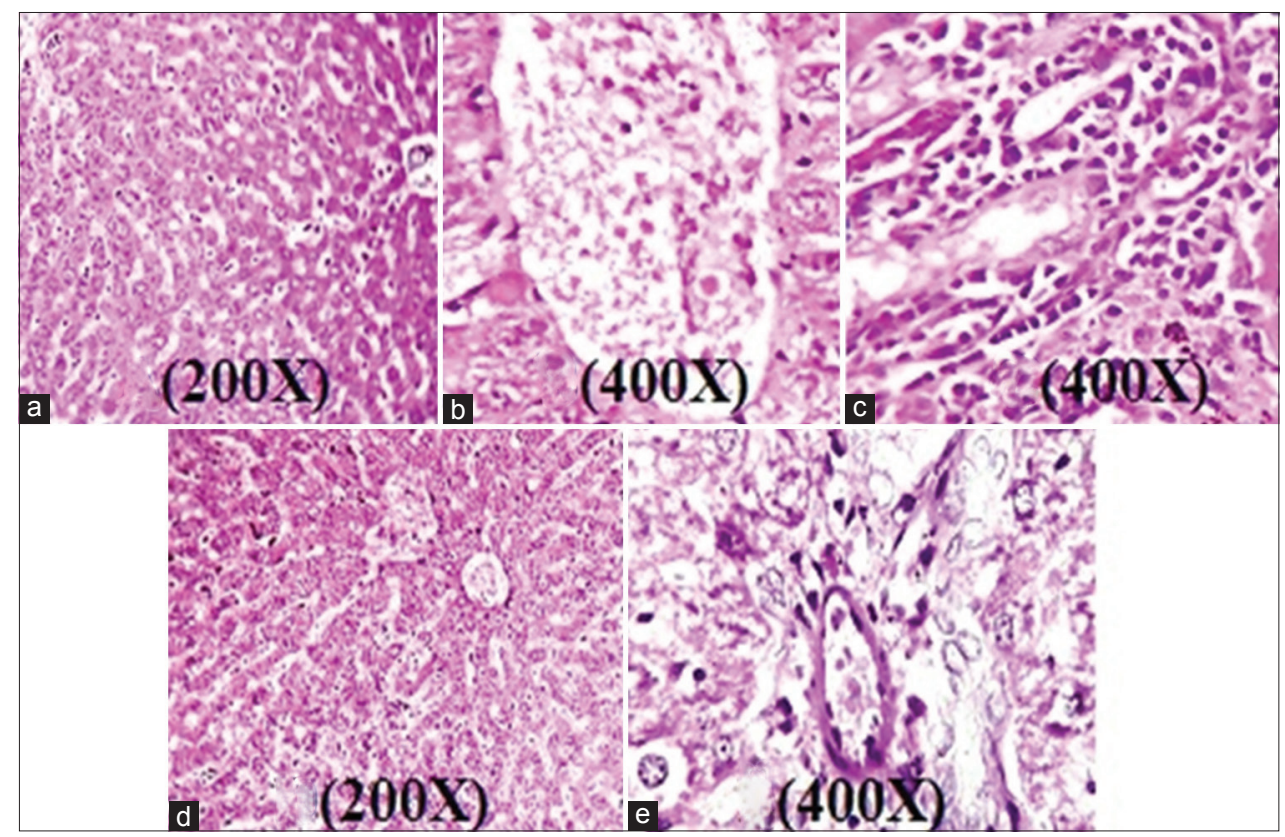

Fig. 1: Histological section showing the effect of lead acetate and treatment of methanolic extract of Cissus quadrangularis on liver tissue (a) normal control (b) Group II - Lead acetate $(25 \mathrm{mg} / \mathrm{kg}$ of body weight) (c) Group III - Extract of C. quadrangularis (50 mg/kg of the body weight) and lead acetate, (d) Group IV treated with $100 \mathrm{mg} / \mathrm{kg}$ of body weight of methanolic extract of $C$. quadrangularis and lead acetate,

(e) Group V - C. quadrangularis $(200 \mathrm{mg} / \mathrm{kg}$ of body weight) along with lead acetate

\section{ACKNOWLEDGMENT}

The authors are thankful to VIT University, Vellore, for providing the infrastructural facility for carrying out the work.

\section{REFERENCES}

1. Goyer RA. Lead toxicity: Current concerns. Environ Health Perspect 1993;100:177-87.

2. Barbosa JF, Tanus-Santos JE, Gerlach RF, Parsons PJ. A critical review of biomarkers used for monitoring human exposure to lead: Advantages, limitations, and future needs. Environ Health Perspect 2005;113(12):1669-74

3. Kirtikar KR, Basua BD. Indian Medicinal Plants. Vol. 2. Dehradun: International Book Distributors; 1987. p. 604.

4. Stohs SJ, Ray SD. A review and evaluation of the efficacy and safety of Cissus quadrangularis extracts. Phytother Res 2013;27(8):1107-14.

5. Mehta M, Kaur N, Bhutani KK. Determination of marker constituents from Cissus quadrangularis Linn. and their quantitation by HPTLC and HPLC. Phytochem Anal 2001;12(2):91-5.

6. Kumar G, Banu GS, Kannan V, Pandian MR. Antihepatotoxic effect of beta-carotene on paracetamol induced hepatic damage in rats. Indian $\mathrm{J}$ Exp Biol 2005;43(4):351-5.

7. Lowry OH, Rosebrough NJ, Farr AL, Randall RJ. Protein measurement with the folin phenol reagent. J Biol Chem 1951;193:265-75.

8. Moron MS, Depierre JW, Mannervik B. Levels of glutathione, glutathione reductase and glutathione $\mathrm{S}$ transferase activities in rat lung and liver. Biochim Biophys Acta 1979;582:67-78.

9. Ohkawa $\mathrm{H}$, Ohishi N, Yagi K. Assay for lipid peroxides in animal tissues by thiobarbituric acid reaction. Anal Biochem 1979;95(2):351-8.

10. Marklund SL, Marklund G. Involvement of superoxide anion radical in the autooxidation of pyrogallol and a convenient assay for superoxide dismutase. Eur J Biochem 1974;47:469-74

11. Sinha AK. Colorimetric assay of catalase. Anal Biochem 1972;47:389-94.

12. Asha DS, Blossom B. Hepatoprotective role of Spirulina fusiformis on methotrexate induced liver injury in Wistar rats. Res J Biotechnol 2016;11(9):58-64

13. Viswanatha Swamy AH, Kulkarni RV, Thippeswamy AH, Koti BC, Gore A. Evaluation of hepatoprotective activity of Cissus quadrangularis stem extract against isoniazid-induced liver damage in rats. Indian J Pharmacol 2010;42(6):397-400

14. Babiak RM, Campello AP, Carnieri EG, Oliveira MB. Methotrexate: Pentose cycle and oxidative stress. Cell Biochem Funct 1998;16(4):283-93.

15. Unnati S. Cissus quadrangularis L.: Phytochemicals, traditional uses and pharmacological activities- a review. Int J Pharm Pharm Sci 2011;3(4):41-4.

16. Srinivasa RS, Sreedhara KR, Kumar MB. Preventive role of Emblica offcinalis and Cissus quadrangularis on bone loss in osteoporosis. Int J Pharm Pharm Sci 2013;5(4):465-70. 